\title{
IMPLEMENTASI KONSEP AT TAWASUTH AHLUS- SUNNAH WAL JAMA'AH DALAM MEMBANGUN KARAKTER ANAK DI TINGKAT SEKOLAH DASAR (STUDI ANALISIS KHITTAH NAHDLATUL ULAMA)
}

\author{
Fitrotun Nikmah \\ Magister Pendidikan Dasar, Universitas Muria Kudus \\ nikmah.fitri@gmail.com
}

\begin{abstract}
ABSTRAK
Khittah Nahdlatul Ulama, dijelaskan bahwa jika seseorang mampu menerapkan karakter at-Tawasuth dalam kehidupan nyata sehari-hari, maka akan terwujud beberapa sikap yang mulia. Karakter ini dapat diterapkan diberbagai bidang dalam kehidupan manusia. Penelitian ini bertujuan untuk mengetahui; 1). Bagaimana konsep Attawasuth Ahlussunnah Wal Jama'ah yang tertera dalam Khittah Nahdlatul Ulama; 2). Bagiamana Implementasi Konsep Attawasuth Ahlussunnah Wal Jama'ah dalam membangun karakter anak. Penelitian ini menggunakan Metode Riset Perpustakaan (Library research) dengan teknik Analisis Deskriptif Kualitatif. Data penelitian yang terkumpul kemudian dianalisis dengan menggunakan pendekatan deduktif dan pendekatan induktif. Hasil penelitian menunjukkan bahwa Khittah NU merupakan landasan resmi dan kuat bagi warga Nahdlatul Ulama dalam bertindak, bersikap dan mengambil keputusan. Dalam tubuh NU terdapat karakteristik khas warga Nahdlatul Ulama yang menbedakannya dengan warga lain. Dalam mengaktualisasikan karakter At-Tawasut aswaja dalam membangun karakter anak dapat diterapkan melalui beberapa amaliyah-amaliyah NU yang didalamnya mengandung nilai-nilai keagamaan, moral yang mulia. Amaliyah tersebut diantaranya adalah Khotmil Qu'an, Pengajaran, Ziarah Kubur dan pengenalan budaya lainnya. Berdasarkan hasil penelitian ini diharapkan akan menjadi bahan informasi dan masukan bagi para mahasiswa, para tenaga pengajar, para peneliti dan dapat dijadikan rujukan untuk melakukan penelitian selanjutnya.
\end{abstract}

Kata Kunci : konsep at-tawasuth, karakter anak, karakter ahlussunnah wal jamaah.

\section{ABSTRACT}

Khittah of Nahdlatul Ulama is explained that if one is able to apply the character of at-Tawasuth in real life everyday, it will manifest some noble attitudes. This character can be applied in various fields of human life. This 
study aims to determine ; 1) How the concept of Attawasuth Ahlussunnah Wal Jama'ah which is listed in Khittah of Nahdlatul Ulama; 2) How to Implement the Concept of Attawasuth Ahlussunnah Wal Jama'ah in developing children's character. This study uses the Library research methode with Qualitative Descriptive Analysis techniques. The research data which is collected then analyzed by using deductive approach and inductive approach. The results of research show that the Khittah of NU is the canonic and fundamental for Nahdlatul Ulama's citizens in acting and making decisions. The citizens oh NU have typical characteristics of Nahdlatul Ulama who distingish with other citizens. In actualizing the character of At-Tawasut of aswaja to build the children's character can be applied through some behavior in which contain religious values, honorable moral. Those are reciting holy Qu'an, Teaching, visiting the tomb to pray human who has passed away and introduction to other cultural. Based on the results of this study are expected to become information material and suggest for the students, the teachers, researchers and can be used as a reference to conduct further research.

Keywords: konsep at-tawasuth, karakter anak, karakter ahlussunnah wal jamaah. 


\section{PENDAHULUAN}

Pendidikan pada haikatnya (Aziz, 2007: vi) adalah mengembangkan potensi anak didik pada aspek jasmani, memajukan budi pekerti (kekuatan batin), pikiran (Intellect), dan moral yang selaras dengan perkembangan alam dan masyarakatnya. Zakiyah Darajat (2012: 20) juga menyatakan bahwa tujuan dari pendidikan islam adalah untuk menjadikan manusia "Insan Kamil" yang memiliki karakter yang baik dan mulia.

Pada dasawara terakhir ini, kompleksitas permasalahan seputar karakter atau moralitas bangsa Indonesia sudah cukup memprihatinkan. Diakui atau tidak hampir setiap hari, semua media memuat berita tentang permasalahan moral bangsa, mulai dari perusakan fasilitas atau barang orang lain, pencurian, perampokan, tawuran antar pelajar, kebiasaan menyontek saat ujian, seks bebas, pemerkosaan dan berbagai kekerasan terhadap anak dan remaja.

Diungkapkan oleh Zubaedi (2011: 2), kondisi krisis dan dekadensi moral ini menandakan bahwa seluruh pengetahuan agama dan moral yang didapatkannya dibangku sekolah ternyata tidak berdampak terhadap perubahan perilaku manusia Indonesia. Mereka lupa bahwa kecerdasan yang tinggi tidak akan berguna tanpa ada karakter yang baik. Peran karakter bagi diri seorang manusia (Aqib, 2010: 32), adalah ibarat kemudi bagi sebuah kapal. Karakter adalah kemudi hidup yang akan menetukan arah yang benar dalam mengarungi bahtera kehidupan seorang manusia.

Bagi lembaga organisasi terbesar di Indonesia, Nahdlatul Ulama yang sering disebut NU, pendidikan merupakan bagian terpenting dalam organisasi kaitannya dalam pengembangan sumber daya manusia. NU mengamanatkan (Aziz, 2007: vii) bahwa pendidikan bertujuan untuk mewujudkan manusia yang berakhlak, yang menyadari dirinya sebagai khalifah di bumi, yang memiliki kecerdasan intelektual, kecerdasan emosional, dan keceradsan spiritual. Pendidikan diarahkan untuk membentuk karakter (character building) dan meningkatkan skill peserta didik.

Banyak sekali lembaga pendidikan di lingkungan NU baik secara formal maupun nonformal, yang harus kembali menata ulang sistem pembelajarannya dengan menjadikan konsep At-Tawasuth dan karakter lainnya ini lebih prioritas atau mendesak untuk diimplementasikan dengan kembali berpedoman pada Khittah NU.

Nahdlatul Ulama (Aziz, 2007: 184) memiliki kerangkan berfikir yang didasarkan pada ajaran Ahlussunnah Wal Jama'ah yang akhirnya menghasilkan Khittah Nahdlatul Ulama. Khittah ini diterapkan menurut kemasyarakatan di Indonesia dan digali dari intisari sejarah NU.

> Fitrotun Nikmah | Implementasi Konsep At Tawasuth Ahlus- Sunnah Wal Jama'ah Dalam Membangun Karakter Anak Di Tingkat Sekolah Dasar (Studi Analisis Khittah Nahdlatul Ulama) 
Sudah sangat jelas dalam Khittah Nahdlatul Ulama ini, disebutkan (Siddiq, 2005: 59) bahwa warga Nahdlatul Ulama memiliki karakteristik tersendiri yang membedakannya dengan kelompok lain. Karakter tersebut adalah at-Tawasuth (pertengahan), al-l'tidal (tegak lurus) dan at-Tawazun (keseimbangan).

Termaktub juga dalam khittah Nahdlatul Ulama (Muzadi, 2006: 27), jika warga NU mau menanifestasikan apa yang dilandaskan pada dasar-dasar keagamaan serta karakteristik diatas, terutama Attawasuth yang merupakan tumpuan dari serangkaian sikap, maka akan menciptakan beberapa sikap terpuji dan beradab. Untuk itulah karakter at-Tawasuth,(Siddiq, 2005: 38) merupakan karakter agama Islam yang paling essensial, dan sasaran yang utama adalah di lembaga pendidikan dasar dimana yang menjadi objeknya adalah para anak - anak. Karena pendidikan agama di disekolah dasar mempunyai peranan yang sangat peting, diungkapkan oleh Syamsyu Yusuf dan Nani M. Sugandhi (2011: 69), yang mengutip pernyataan dari Zakiyat Darajat, bahwa pendidikan agama disekolah dasar merupakan dasar bagi pembinaan sikap positif terhadap agama, pembentukan kepribadian dan akhlak anak. Apabila berhasil, maka pengembangan sikap keagamaan pada masa remaja akan mudah, karena anak telah mempunyai pegangan atau bekal dalam menghadapi berbagai goncangan yang biasa terjadi pada masa remaja.

Dari sinilah penulis tertarik untuk mengkaji bagaimana mengimplementasikan konsep at-Tawasut Ahlussunnah Wal Jama'ah yang dijadikan salah satu jalan untuk membangun karakter anak. Dalam hal ini, penulis akan mencoba menganalisis isi Khittah Nahdlatul Ulama yang menjadi landasan berfikir, bersikap warga Nahdlatul Ulama kaitannya dengan penerapan karakter at-Tawasuth diberbagai bidang kehidupan.

Penelitian ini bertujuan untuk memberi dan menambah wacana tentang konsep at-Tawasuth Ahlussunnah Wal Jama'ah yang tertera dalam Khittah Nahdlatul Ulama dan mengkaji Implementasi Konsep At-tawasuth Ahlussunnah Wal Jama'ah dalam Membangun karakter.

Disebutkan oleh KH Ahmad Shiddiq (2005: 9), ada tiga istilah untuk menggambarkan karakteristik agama Islam, yang kemudian diadopsi sebagai karakteristik khas warga Nahdlatul Ulama, yaitu : at-Tawasuth, al-l'tidal dan atTawazun. At Tawasuth (Siddiq, 2005: 60) yang berarti pertengahan. Al-i'tidal berarti tegak lurus, tidak condong ke kanan-kananan dan tidak condong ke kiri-kirian, dan 
at-Tawazun berarti keseimbangan, tidak berat sebelah, tidak berlebihan suatu unsur atau kekurangan unsur yang lain.

At-tawasuth termasuk al-l'tidal dan at-Tawazun (Shiddiq, 2006: 60) bukan serba kompromistik dengan mencampuradukkan semua unsur (sinkretisme). Juga bukan mengucilkan diri dari menolak pertemuan dengan unsur apa-apa. Karena karakter bagi Islam adalah memang sejak semula Allah SWT. Sudah meletakkan di dalam Islam segala kebaikan, dan segala kebaikan itu pasti terdapat di antara ujung Tatharruf ( النطرف ), sifat mengujung, ekstrimisma.

Anggapan mengabungkan semua karakter lainnya dengan karakter at-tawasuth, bahwa secara konteks semua kata-kata tersebut memang ujungnya pada maksud yang sama yaitu menempatkan diri di tenggah-tengah dalam menghadapi sesuatu. Namun tetap saja dari semua karakter tersebut ada sekat-sekatnya.

Karakter at-tawasuth (Hasan, 2010: 70) harus mampu dimanifestasikan dalam berbagai bidang, agar nantinya sikap dan tingkah laku umat Islam dapat dijadikan sebagai teladan dan ukuran manusia pada umumnya. Karena Nahdlatul Ulama dengan sikap dasar ini akan selalu menjadi kelompok panutan yang bersikap dan bertindak lurus dan selalu bersifat membangun serta menghindari segala bentuk pendekatan yang bersifat ekstrim.

Untuk itulah karakter at-Tawasuth, (Siddiq, 2005: 38) merupakan karakter agama Islam yang paling essensial. Maka semua warga Nahdlatul Ulama berpendirian faham Ahlussunnah Wal Jama'ah harus diterapkan dalam tata kehidupan nyata di masyarakat dengan serangkaian sikap yang bertumpu pada karakter at-Tawasuth.

Secara etimologi, kata karakter berasal dari bahasa Inggris (character) dan Yunani (character) yang berarti membuat tajam, membuat mendalam. Karakter juga bisa diartikan sebagai tabiat, perangai atau perbuatan yang selalu dilakukan (kebiasaan). Karakter juga diartikan sebagai watak atau sifat batin manusia yang mempengaruhi segenap pikiran dan tingkah laku.

Menurut Thomas Lickona sebagaimana dikutip oleh Agus Wibowo (2012: 32), karakter merupakan sifat alami seseorang dalam merespon situasi secara bermoral. Sifat alami itu dimanifestasikan dalam tindakan nyata melalui tingkah laku yang baik, jujur, bertanggungjawab, menghormati orang lain dan karakter mulia lainnya.

Kemudian dikemukakan pula oleh Miyara, (2013: 25), bahwa karakter adalah kualitas atau kekuatan mental atau moral, akhlak atau budi pekerti individu yang

> Fitrotun Nikmah | Implementasi Konsep At Tawasuth Ahlus- Sunnah Wal Jama'ah Dalam Membangun Karakter Anak Di Tingkat Sekolah Dasar (Studi Analisis Khittah Nahdlatul Ulama) 
merupakan kepribadian khusus yang menjadi pendorong dan penggerak, serta yang menbedakan dengan individu lainnya. Jadi seseorang dikatakan berkarakter, jika telah berhasil menyerap nilai dan keyakinan yang dikehendaki masyarakat, serta digunakan sebagai moral dalam hidupnya.

Periode pertama dalam kehidupan anak, yakni pada usia 6 tahun pertama (Kurniasih, 2010:73) merupakan periode yang amat kritis dan paling penting. Periode ini mempunyai pengaruh yang sangat mendalam dalam pembentukan pribadinya. Karena anak pada usia ini memiliki sistem perekam yang sangat cangih di memori otaknya. Jadi apapun akan terekam dalam benak anak nantinya akan memberikan pengaruh yang nyata pada kepribadiannya ketika dewasa.

Diungkapkan Pula oleh Anik Pamilu (2007: 90), pada saat anak memasuki usia $\mathrm{SD}$, mereka sudah mulai mengenal nilai baik dan buruk, sehingga mereka sudah mulai bertindak berdasarkan moralitas. Jadi jika pendidikan moral pada usia ini dilaksanakan dengan baik, selalu dibimbing, diarahkan dan dibantu untuk memahami prinsip nilai dan keyakinan pribadi serta penerapannya, maka ia akan tumbuh menjadi anak yang berkarakter mulia.

Sehingga anak pada usia ini, memerlukan bimbingan, arahan dan contoh yang baik dari semua orang yang ada disekitarnya. Serta orang tua dan lingkungan diharapkan mampu memberikan pengertian dan terhadap apa yang harus dilakukan oleh anak dan nilai, aturan aturan yang ada di masyarakat. Selain itu anak sudah mulai diberi tanggung jawab dan kepercayaan oleh lingkungan dan tetap dengan pengawasan. Dengan semua perlakuan di atas diharapkan perkembangan anak dalam segala aspek dapat berjalan dengan baik.

Dalam melakukan penelitian ini, ada beberapa penelitian sebelumnya yang digunakan peneulis sebagai bahan rujukan, diantaranya buku karya M. Mahbubi, yang berjudul Pendidikan Karakter Implementasi Aswaja, sebagai Nilai Pendidikan Karakter. Buku ini merupakan gubahan dari Tesis yang berjudul "Implementasi Pendidikan Karakter Melalui Pembelajaran Aswaja di SMP Khatijah A. Yani Surabaya" pada program Pascasarjana IAIN Sunan Ampel Surabaya. Dan Jurnal yang ditulis oleh Muhammad Yunus (Dosen Jurusan Pendidikan Bahasa Inggris FKIP UNISMA) dengan judul "Pendidikan Karakter Bangsa berbasis ASWAJA Terintegrasi dalam Pembelajaran Bahasa Inggris". Muhammad Yunus ini mencoba mengungkapkan bahwa ajaran Ahlussunnah Wal Jama'ah ini bersifat fleksibel tidak hanya diterapkan 
pada mata pelajaran agama saja namun pendidikan karakter yang berbasis Ahlussunnah Wal Jama'ah juga bisa terintegrasi dalam pembelajaran Bahasa Inggris.

\section{METODE PENELITIAN}

Dalam penelitian ini, penulis menggunakan pendekatan deskriptif kualitatif. Pendekatan ini (Azwar, 2011: 4), merupakan penelitian yanag temuan-temuannya tidak diperoleh melalui prosedur statistik atau bentuk hitungan lainnya. Dan jenis penelitian di sini menggunakan penelitian kepustakaan. Studi Kepustakaan (Library Research) menurut Hasan Aqbal dalam Khoiri (2012: 115), adalah penelitian yang dilaksanakan dengan menggunakan literatur (kepustakaan), baik berupa buku, catatan maupun laporan hasil penelitian dari penelitian terdahulu.

Sumber yang akan diambil oleh penulis berasal dari beberapa hal baik yang bersifat primer maupun yang bersifat sekunder. Sumber data yang bersifat primer adalah sumber utama yang langsung diperoleh untuk tujuan penelitian. Sumber primer dalam penelitian ini adalah Buku Khittah Nahdliyyah, karya KH Achmad Siddiq. Buku ini merupakan cikal bakal rumusan Khittah Nahdlatul Ulama yang nantinya akan menjadi bahan analisis dalam penelitian ini. Teknik pengumpulan data yang digunakan dalam penelitian ini, adalah; Dokumentasi, penulis mengambil data dari studi kepustakaan dengan jalan mempelajari literatur dan buku-buku dan juga data dari beberapa instantsi atau orang lain yang berkaitan dengan permasalahan sebagai penunjang dan pelengkap dalam memudahkan penelitian ini.

Data-data yang terkumpul disusun secara sistematis kemudian diadakan analisa secara cermat dan lebih ditekankan pada proses penyimpulan induktif, yakni cara berpikir yang didasarkan pada pengetahuan yang bersifat khusus, kemudian dari pengetahuan tersebut dinilai suatu yang bersifat umum.

\section{HASIL PENELITIAN DAN PEMBAHASAN}

Jelas tertera dalam naskah Khittah NU sebagai keputusan Muktamar XXVII NU (Muzadi, 2006: 27), bahwa jika setiap warga NU memahami, menyerapi setiap karakter sikap kemasyarakatan warga Nahdlatul Ulama kemudian diterapkan dalam jiwa dan diwujudkan dalam tindakan nyata sehari hari. Maka akan tercipta beberapa sikap warga NU, diantaranya : Menjunjung tinggi nilai-nilai maupun norma-norma ajaran Islam, Mendahulukan kepentingan bersama daripada kepentingan pribadi, menjunjung tinggi persaudaraan (al-ukhuwah), persatuan (al-ittihad) serta kasih

> Fitrotun Nikmah | Implementasi Konsep At Tawasuth Ahlus- Sunnah Wal Jama'ah Dalam Membangun Karakter Anak Di Tingkat Sekolah Dasar (Studi Analisis Khittah Nahdlatul Ulama) 
mengasihi, meluhurkan kemuliaan moral (al-akhlaq al-karimah) dan menjunjung tinggi kejujuran (ash-shidqu) dalam berfikir, bersikap dan bertindak.

NU memiliki karakteristik yang khas yang membedakannya dengan warga lainnya. Salah satunya adalah karakter at-tawasuth sebagai karakter dasar warga NU yang sangat penting untuk diterapkan di berbagai bidang dalam tindakan nyata sehari-hari.

Memanifestokan prinsip dan karakter ini pada segala bidang ajaran agama islam, harus selalu dipertahankan, dipelihara dan dikembangkan sebaik-baiknya agar keberadaannya jelas dan tak mudah terpenggaruh dan tergeserkan oleh aliran-aliran. Apalagi dizaman modern saat ini yang sudah sangat banyak kita temukan berbagai persoalan kemerosotan moral. Sehingga perlu adanya gerakan revitalisasi kembali karakter-karakter mulia untuk membangun bangsa yang mulia.

Secara umum, Ratna Megawangi sebagaimana dikutip oleh Q-Anees dan Hambali (2008: 107), menengarai perlunya metode $4 \mathrm{M}$ dalam penerapan pendidikan Karakter, yaitu Mengetahui, mencintai menginginkan dan mengerjakan (Knowing the good, loving the good, desiring the good, and acting the good) kebaikan yang dilakukan secara simultan dan berkesinambungan.

Metode di atas menunjukkan bahwa karakter harus dilakukan dengan kesadaran yang utuh. Kesadaran utuh disini adalah sesuatu yang dilaksanakan secara sadar, diketahui dengan sadar, dilakukan dengan rasa cinta dan benar-benar diinginkan, tanpa paksaan untuk melakukannya. Jika sesuatu itu dilaksanakan dengan utuh dan sadar maka akan

Sedikit lebih luas dikemukakan Oleh Gunawan (2013: 38), karakter dikembangkan melalui tahap pengetahuan (knowing), pelaksanaan (acting), dan kebiasaan (habit). Pengajaran karakter tidak sebatas hanya pada pengetahuan saja. Seseorang yang memiliki segudang pengetahuan tentang nilai kebaikan namun tidak mampu bertindak sesuai dengan pengetahuannya, maka akan sia-sia saja. Namun jika pengetahuan tersebut dilaksanakan dan dilatih terus-menerus sehingga menjadi kebiasaan, maka pengetahuan tersebut akan menjadi karakter yang kokoh dalam diri seseorang.

Dimensi-dimensi diatas sesuai dengan beberapa aspek domain pendidikan yang dikembangkan di Indonesia, yaitu tahap pengetahuan (knowing) mengisi ranah kognitif, kemudian pelaksanaan (acting) mengisi ranah Psikomotorik, dan kebiasaan (habit) mengisi pada aspek Afektif. 
Kemudian dalam penerapannya di lembaga sekolah, Doni A. Koesoema sebagaimana dikutip oleh Q-Anees dan Hambali (2008: 108), mengajukan lima metode pendidikan karakter, yaitu: mengajarkan, keteladanan, menentukantukan prioritas, Praktis prioritas atau pelaksanaan prioritas dan refleksi atau pemantulan diri dari apa yang sudah dikerjakan.

Metode pengajaran sangat mutlak diperlukan dalam menanamkan karakter atau nilai pada anak. Sebagaimana yang diungkapkan oleh Kurniasih dam (2010: 44), karakter atau nilai-nilai tersebut memang terlalu mengawang-awangan untuk anakanak, akan tetapi para pendidik harus mampu memberi pemahaman sedikit demi sedikit pada anak terhadap makna-makna segala sesuatunya, terutama terhadap fenomena dan pengalaman yang mereka hadapi atau alami.

Jadi meskipun penerapan karakter sudah memenuhi semua domain dan sesuai dengan aspek perkembangan anak, yang paling dibutuhkan saat ini adalah teladan dari semua pihak, baik itu dari orang tua, guru, masyarakat,dan juga pemerintah. Bukan hanya orang-orang yang harus dituntut untuk memberi teladan tapi semua sumber referensi yang ada di sekitar anak juga harus memberikan contoh yang baik sesuai dengan karakter yang baik yang ingin dikembangkan dalam diri anak.

Konsep at-tawasuth adalah suatu nilai yang bersikap awang-awangan bagai anak. Dalam mengajarkan suatu nilai bersifat awang-awangan, para orang tua dan pendidik harus mampu memberikan pemehaman yang sedikit demi sedikit terhadap makna-makna segala sesuatunya. Nilai-nilai tersebut akan lebih mengena pada jiwa anak jika mampu dibenturkan pada fenomena dan pengalaman yang mereka hadapi atau mereka temukan.

Sekolah mampu memberikan pembelajaran yang tearah, terstruktur dan berjenjang, sebagaimana yang diungkapkan oleh Sagala (2008: 231) bahwa Pendidikan formal adalah lembaga yang disebut dengan sekolah yang merupakan bagian dari pendidikan yang berjenjang dan berkesinambungan. Sekolah berfungsi untuk mempertahankan dan mengembangkan tatanan-tatanan sosial serta kontrol sosial melalui program-program atau kurikulum yang diberikan.

Dalam meciptakan suatu sekolah yang berbasis pendidikan karakter dapat diterapkan melalui manajemen sekolah yang berkarakter, mengintregasikan pendidikan karakter dalam proses pembelajaran, pengembangan budaya sekolah berbasis pendidikan karakter dan menggunakan ekstrakulikuler sebagai wahana pendidikan karater.

> | Fitrotun Nikmah | Implementasi Konsep At Tawasuth Ahlus- Sunnah Wal Jama'ah Dalam Membangun Karakter Anak Di Tingkat Sekolah Dasar (Studi Analisis Khittah Nahdlatul Ulama) 
Implementasi khittah NU tentang konsep at-Tawasuth ahlus sunnah wal jamaah dalam membangun karakter anak secara garis besar meliputi:

1. Pada bidang Akidah.

Keseimbangan dalam penggunaan dalil 'aqli dan dalil naqli. Dengan pengertian dalil aqli ditempatkan dibawah dalil naqli. NU mengenal hirarki sumber ajaran Islam sebagaimana dilakukan oleh mayoritas umat Islam, yaitu mulai AI-Quran, sunnah, ij'ma' (kesepakatan jumhur ulama'), dan qiyas (pengambilan hukum melalui analogi tertentu.

2. Pada Bidang Akhlak.

Ahlussunnah wal Jamaah berupaya untuk membimbing manusia dalam mencapai derajat keikhlasan. dan dasar yang paling penting diajarkan kepada anak adalah tauhid. Selain itu untuk menciptakan suatu kehidupan yang baik harus selalu berlaku seimbang dalam urusan hablun min Alla) dan hablun min al-nasatau nilai tauhidiyan dan nilai insaniyah.

3. Pada Bidang Pergaulan antar golongan

Penerapan Karakter at-tawasuth (moderat) menerapkan sikap menghargai plurarisme yang berlandaskan pada nilai-nilai plural, moderat, dan adil dalam ukhuwwah nahdliyyiah, baik ukhuwah Islamiyah, ukhuwah wathaniyah, atau pun ukhuwah insaniyah,

4. Pada Bidang Kebudayaan

Perilaku budaya kaum nahdliyyin adalah menempatkan kebudayaan dengan segala manifestasinya pada posisi yang wajar. Dan menyikapi kebudayaan dengan ukuran nilai atau norma-norma hukum dan ajaran agama. Sehingga akan menghasilkan sikap menghargai suatu kebudayaan dan tidak berlebih-lebihan dalam menilai budaya asing.

Pada hakikatnya, dalam amaliyah NU sudah terdapat nilai-nilai ynag tepat untuk digunakan dan diterapkan di beberapa lembaga pendidikan sekolah dasar sebagai sarana untuk mengaktualisasikan konsep At Tawasuth Ahlus Sunnah Wal Jamaah dalam membangun karakter Anak.

1. Bidang Akidah.

Kaum Nahdliyin sangat akrab dengan budaya khatmil Quran, yaitu mengatamkan kitab suci Al-Quran dalam sehari secara bersama-sama. Amaliyah ini sangat penting diajarkan kepada anak, karena melalui khotmil Quran, anak-anak akan terbiasa mengamalkan Al-Quran dalam dirinya. Selain itu mengajarkan kandungan 
atau maksud yang terdapat pada suatu ayat kepada anak juga sangat penting, sehingga anak-anak tersebut akan mampu mengambil pelajaran dari ayat-ayat AlQuran tersebut dan menjadikannya sebagai pedoman dalam kehidupan seharihari.

\section{Bidang Pendidikan}

Melalui pengajaran, Pengenalan atau penanaman pengertian nilai pada anak merupakan hal yang sangat penting karena tanpa mengetahui maksud dari suatu nilai tersebut ketika anak mengerjakannya maka anak tersebut hanya sekedar mengerjakan tanpa paham apa maksud, tujuan dan fungsi suatu nilai tersebut bagi anak. Dan cara yang paling efektif untuk menanamkan pengertian nilai pada anak adalah melalui pengajaran atau pendidikan.

Pengajaran nilai attawasuth dapat menggunakan strategi $3 \mathrm{M}$ (Moral Knowing, Moral Loving and Moral Doing), Sebagaimana yang diungkapkan oleh Gunawan (2012: 193-194), moral knowing merupakan langkah pertama dalam pendidikan karakter, dimana dalam langkah ini diorientasikan pada penguasaan pengetahuan tentang nili-nilai. Selanjutnya moral loving merupakan penguatan aspek emosi dan afektif anak untuk menjadi manusia karakter, dimana dalam langkah ini diharapkan anak mampu mencintai dan merasa butuh terhadap nilai-nilai akhlak mulia. Dan terakhir moral doing menyentuh pada ranah psikomotorik, dimana anak mampu melakukan atau bertindak sesuai dengan nilai-nilai yang tertanam dalam diri anak.

3. Bidang Kebudayaan

Aktualisasi penerapan karakter at-Tawasuth pada bidang kebudayaan dapat dilakukan melalui pemahami, mengikuti dan membiasakan amaliyah-amaliyah budaya NU yaang sudah mengalami proses Islamisasi. Amaliyah-amaliyah tersebut, diantaranmya adalah: kupatan, mitoni, khajatan dan lainnya.

Pengenalan tradisi-tradisi seperti ini atau tradisi lain yang mengalami islamisasi misalnya tradisi ngapati dan mitoni pada wanita hamil, syuronan, ruwahan dan tradisi lainnya pada anak juga sangat penting. Dengan memahami tradisi-tradisi tersebut maka akan tertanam dalam jiwa anak untuk tidak memandang secara berlebihan terhadap tradisi, serta tidak phobia terhadang budaya asing.

Selain itu keikutsertaan anak-anak dalam pengadaan tradisi-tradisi tersebut akan menimbulkan rasa ukhuwah (persaudaraan) terhadap sesama karena disini anak dibiasakan untuk berhubungan dengan orang lain.

> Fitrotun Nikmah | Implementasi Konsep At Tawasuth Ahlus- Sunnah Wal Jama'ah Dalam Membangun Karakter Anak Di Tingkat Sekolah Dasar (Studi Analisis Khittah Nahdlatul Ulama) 


\section{Bidang Pergaulan Antar Golongan}

Dalam menanamkan karakter at-tawasuth dalam bidang pergaulan antar golongan, dapat dilakukan dengan mengikut sertakan anak pada kegiatan ziarah (kunjungan) ke makam para wali, sesepuh, dan para guru. Kemudian mengenalkan Budaya,Agama, Suku lain.

Beberapa amaliyah NU diatas dapat digunakan sebagai sarana untuk aktualisasi Implementasi karakter at-tawasuth dalam diri anak. Selain amaliah diatas penulis berpendapat bahwa pengenalan agama, suku, ras dan budaya lain juga perlu karena dengan sedikit tahu keberadaan agama lain, anak- anak akan mampu menghormati agama, suku, ras dan budaya lain. Dengan munculnya sikap menghormati terhadap yang lain maka secara tidak lansung akan muncul sikap menghargai pluralisme dalam diri anak.

Dengan tumbuh rasa menghargai pluralisme dalam diri anak, akan selalu tertanam dalam diri anak pula untuk tidak bersifat fanatik pada hal yang diyakininya dan tidak akan ada rasa menganggap salah pada agama, suku, ras dan budaya lain diluar yang diyakininya.

Amaliyah-amaliyah NU diatas, dapat digunakan sebagai sarana menanamkan karakter At-Tawasuth dalam diri anak melalui mengintregasikan pada pembelajaran atau digunakan sebagai progam ektrakulikuler wajib pada anak.

\section{KESIMPULAN}

Berdasarkan hasil penelitian dan analisis penulis, dapat diambil kesimpulan yang merupakan jawaban atas tujuan penelitian ini, yaitu: dalam Implementasi khittah NU tentang konsep at-Tawasuth ahlus sunnah wal jamaah dalam membangun karakter anak secara garis besar dapat dilakuakn dalam berbagai aspek kehidupan sehari-hari, yaitu pada bidang Akidah, pada Bidang Akhlak, pada Bidang Pergaulan antar golongan dan pada Bidang Kebudayaan

Berdasarkan hasil kajian, Aktualisasi konsep At Tawasuth Ahlus Sunnah Wal Jamaah dalam membangun karakter anak dapat dilakukan melalui Beberapa amaliah yang ada dalam NU, melalui : Bidang akidah melalui khatmil qur'an, Bidang pendidikan melaui pengajaran dan kitab rujukan, Bidang kebudayaan melalui kupatan atau pengenalan tradisi lainnya dan Bidang hubungan antar golongan melalui ziarah kubur, Kitab Rujukan dan pengenalan agama, suku, ras dan budaya lain untuk menumbuh rasa menghargai pluralism. 
Penerapan Karakter At-Tawasuth Ini paling efektif dilakukan di lembaga sekolah melalui manajemen sekolah yang berkarakter, mengintregasikan pendidikan karakter dalam proses pembelajaran, pengembangan budaya sekolah berbasis pendidikan karakter dan menggunakan ekstrakulikuler sebagai wahana pendidikan karater.

Dari paparan hasil penelitian ini, penulis memberikan masukan sebagai saran dalam penelitian ini sebagai berikut: Penelitian ini dapat dijadikan tambahan referensi untuk kontrol diri (self-control) semua pendidik baik orang tua dan guru dalam mengajar dan mendidik. Serta dapat digunakan sebagai bahan rujukan untuk melakukan penelitian selanjutnya.

\section{DAFTAR PUSTAKA}

Aqib, Zainal, 2010, Pendidikan Karakter Membangun Perilaku Positif Anak Bangsa, Bandung:Yrama Widya.

Azwar, Saifudin, 2011, Metode Penelitian,Yogjakarta: Pustaka Pelajar, cet xii Darajat, Zakiyah, 2012, IImu Pendidikan Islam, Jakarta: Bumi Aksara.

Darajat, Zakiyah, 1994, Pendidikan Islam dalam Keluarga dan Sekolah, Jakarta;Ruhama.

Gunawan, Heri, 2013, Pendidikan Karakter Konsep dan Implementasi, Bandung; Alfabeta.

Gunawan, Heri, 2012, pendidikan Karakter,Bandung;Alfabeta.

Hasan, Nur, 2010, ljtihad Politik NU, Yogyakarta;Manhaj.

Kurniasih, Imas, 2010, Mendidik SQ Anak Menurut Nabi Muhammad.SAW, Yogyakarta;Pustaka Marwa..

Mahbubi, 2012, Pendidikan Karakter, Implementasi Aswaja sebagai Nilai Pendidikan Karakter, Jogjakarta:Pustaka IImu.

Majid, Abdul dan Dian Andayani, 2011, Pendidikan Karakter Peerspektif Islam, Bandung;Remaja Rosdakarya.

Muhammad Yunus, "Pendidikan Karakter Bangsa berbasis ASWAJA Terintegrasi dalam Pembelajaran Bahasa Inggris". http://www.fkipunisma.ac.id/bahasainggris, (diakses 15 Juni 2017)

Muzadi, Abdul Muchid, 2006, Mengenal Nahdlatul Ulama Surabaya:Khalista. , 2006, NU dalam Perspektif Sejarah dan Ajaran, Surabaya; Khalista.

Pamilu, Anik, 2007, Mendidik Anak Sejak dalam Kandungan, Yogyakarta;Citra Media. 
92 | Jurnal Tarbawi Vol. 15. No. I. Januari - Juni 2018

Q-Anees, Bambang, dan Adang Hambali, 2008, Pendidikan Karakter berbasis Al Quran, Bandung;Simbiosa Rekatama Media.

Shiddiq, Achmad, 2005, Khittah Nahdliyyah, Surabaya: Khalista.

Wibowo, Agus, 2012, pendidikan karakter strategi membangun karakter bangsa berperadaban,Yogjakarta;Pustaka Pelajar. , 2012, Pendidikan Karakter Usia Dini, Yogjakarta,Pustaka Pelajar.

Wijaya, Novan Ardy, 2013, Membumikan Pendidikan Karakter di SD, Jogjakarta;ArRuzz Media.

Yusuf, Syamsyu, dan Nani M. Sugandhi, 2011, Pengembangan Peserta Didik, Jakarta: rajawali Press.

Zubaedi, 2011, Desain Pendidikan Karakter Konsepsi dan Aplikasi dalam Lembaga Pendidikan, Jakarta; Kencana.

Zuhri, Achmad Muhibbin, 2010, Pemikiran KH.M. Hasyim Asyari tentang Ahl al sunnah wa al jamaah, Surabaya; Khalista. 